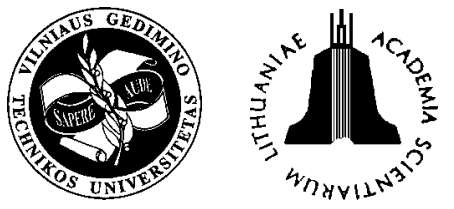

\title{
THE RESEARCH INTO THE INFLUENCE OF ECOLOGICAL PETROL ADDITIVES IN THE AUTOMOBILE LABORATORY
}

\author{
Algis Butkus ${ }^{1}$, Saugirdas Pukalskas ${ }^{2}$ \\ Dept of Automobile Transport, Vilnius Gediminas Technical University, \\ J. Basanavičiaus g. 28, LT-03224 Vilnius-09, Lithuania.
}

Received 2003-11-18; accepted 2004-01-15

\begin{abstract}
Looking forward to Lithuania becoming a member of the EU it is very important to use a larger amount of renewing fuel. Based on economic and environmental considerations in Lithuania, we are interested in studying the effects of ethanol contents in the blended ethanol-petrol fuel on the engine performance and pollutant emission of SI engine. Therefore, we used engine test facilities to investigate the effects on the engine performance and pollutant emission of 3,5\% and 7,0\% ethanol in the fuel blend and special additives, which reduce emissions and increase octane rating. The tests were carried out in the laboratory on a chassis dynamometer with two different cars. The experiment results showed that ethanol used in a fuel blend with petrol had a positive influence on engine performance and exhaust emission.
\end{abstract}

Keywords: alternative fuel; renewable fuel; fuel additives; ethanol; spark ignition engines; internal combustion engines; exhaust emission.

\section{Introduction}

Ethanol has been known as a fuel for many decades. Indeed, when Henry Ford designed the Model T, it was his expectation that ethanol, made from renewable biological materials, would be major automobile fuel. However, it is not widely used because of its high price. But as fuel for spark-ignition (SI) engines, ethanol has some advantages over petrol, such as better anti-knock characteristics and less of $\mathrm{CO}$ and UHC emissions. Although having these advantages, due to limitation in technology, economic and regional considerations, alcohol fuel still cannot be used extensively. Since ethanol can be fermented and distilled from biomasses, it can be considered as a renewable source of energy. Under the environmental consideration, using ethanol blended with petrol is better than pure petrol because of its renewability and less toxicity.

Looking forward to Lithuania becoming a member of the EU it is very important to use a larger amount of renewing fuel. Based on economic and environmental considerations in Lithuania, we are interested in studying the effects of ethanol contents in the blended ethanol-petrol fuel on the engine performance and pollutant emission of SI engine.

\footnotetext{
${ }^{1}$ E-mail: tiauto@ti.vtu.lt

2 E-mail: Saugirdas.Pukalskas@ti.vtu.lt
}

Twenty years ago the interest in alternative fuels rose also because of the increase of environment pollution with harmful combustion products. In accordance with the EU requirements the Law of Biological Fuels Nr. VIII-1875 was passed in Lithuania on June 18, 2000 which provides for the use of spirits of vegetable origin and rape oil as raw materials $[1,2]$.

Aspects of the use of ethanol were examined abroad and also at the Vilnius Gediminas Technical University (VGTU) [3-8].

Ethanol $\left(\mathrm{C}_{2} \mathrm{H}_{5} \mathrm{OH}\right)$ is a pure substance. However, petrol is composed of $\mathrm{C}_{4}-\mathrm{C}_{12}$ hydrocarbons and has wider transitional properties. Ethanol contains an oxygen atom so that it can be viewed as a partially oxidized hydrocarbon. Ethanol is completely miscible with water in any proportion, while the petrol and water are immiscible [9]. This may cause the blended fuel to contain water, and further result in the corrosion problems of the metallic components, especially of the components made of copper, brass or aluminium.

As the combustion characteristics, the auto-ignition temperature and flash point of ethanol are higher than those of petrol, it makes it safer for transportation and storage. The latent heat of evaporation of ethanol is 3-5 times higher than that of petrol; this makes the temperature of the intake manifold lower, and increases the volumetric efficiency. The heating value of ethanol is lower 
than that of petrol. Therefore, we need 1,6 times more ethanol to achieve the same energy output. The stoichiometric air-fuel ratio (AFR) of ethanol is about $2 / 3$ that of the petrol, so the required amount of air for complete combustion is less for alcohol (AFR for air - petrol mixture is 14,7 , for air - ethanol $-9,07)$.

The air pollution caused by automobiles and motorcycles is one of the important environmental problems to be solved. Since using ethanol-petrol fuel blends can ease off the air pollution and the depletion of petroleum fuels simultaneously, many researchers $[3,10,11]$ have been devoted to studying the effect of these alternative fuels on the engine performance and pollutant emission. Palmer [12] used various blend rates of ethanol-petrol fuels in engine tests. Results indicated that $10 \%$ ethanol addition increases the engine power output by $5 \%$, and the octane number can be increased by $5 \%$ for each $10 \%$ of ethanol added. Abdel-Rahman and Osman [13] recently have tested $10 \%, 20 \%, 30 \%$ and $40 \%$ of ethanol in blended fuels in a variable-compression-ratio engine. They found that the increase of ethanol content increases the octane number, but decreases the heating value. The $10 \%$ addition of ethanol had the most obvious effect on increasing the octane number. Under various compression ratios of engine, the optimum blend rate was found to be $10 \%$ ethanol with $90 \%$ petrol.

Bata et al. [14] studied different blend rates of ethanol-petrol fuels in engines and found that the ethanol could reduce the CO and UHC emissions to some degree. The reduction of $\mathrm{CO}$ emission is apparently caused by the wide range of flammability and oxygenated characteristic of ethanol. In the study [12] Palmer indicated that $10 \%$ of ethanol addition to petrol could reduce the concentration of $\mathrm{CO}$ emission up to $30 \%$. However, using ethanol-petrol fuel blends increases the emission of acetaldehyde and acetone 5,12-13,8 times than those of petrol. Although the emission of aldehyde will increase when we use ethanol as a fuel, the damage to the environment by the emitted aldehyde is far less than that by the poly-nuclear aromatics emitted from burning petrol. Therefore, using higher percentage of alcohol in blended fuel can make the air quality better [15] in comparison with petrol.

After the literature review, we understood that alcohol-petrol fuel blends can effectively reduce the pollutant emission without modifications of the engine. Moreover, the ethanol can be made from biomasses. These factors make it appealing to us in Lithuania. We therefore used engine test facilities to investigate the effects on the engine performance and pollutant emission of 3,5\% and 7,0\% ethanol in the fuel blend and special additives ("OP" and "EKO"), which reduce emissions and increase octane rating.

\section{Goal and method of the research}

The opportunity occurred and a decision was made to test additives which now can be found in the market. The tests were carried out in the Maintenance laboratory of the Automobile transport department of VGTU for two cars: Golf IV 1,6116 V (car number plate RVP 420) and VAZ-21093 (car number plate NVR 641). Test speed $-60 \mathrm{~km} / \mathrm{h}$, loadings $-10,15,20 \mathrm{~kW}$ and maximum power, "run" on the chassis dynamometer. For normal engine temperature conditions a fan, blowing to the car from the front was arranged. Feeding systems were left unchanged. Engine exhaust gases were measured by the analysing meter AVL DiGas 465, fuel consumption - by the instrument AIC 2022 L-Jetronic, engine power, torque and power on wheels - by the chassis dynamometer MAHA LPS 2000. Instrumental errors not exceeded from $\pm 1 \%$ to $\pm 2 \%$. There are notations used in the text of the fuel blends in table.

The notations of the fuel blends

\begin{aligned} & Column headings Meanings \\ & \hline $3,5 \% \mathrm{E}- \begin{array}{l}\text { blend of petrol and 3,5\% } \\ \text { ethanol; } \\ \text { blend of petrol and 7,0\% } \\ \text { ethanol; } \\ \text { blend of petrol and 3,5\% } \\ \text { ethanol with patented leadless } \\ \text { antiknock additive; } \\ \text { blend of petrol and 7,0\% } \\ \text { ethanol with patented leadless } \\ \text { antiknock additive; } \\ \text { blend of petrol and 1\% } \\ \text { ethanol with patented additive, } \\ \text { reducing the amount of } \\ \text { harmful components in the } \\ \text { exhaust gases; } \\ \text { blend of petrol and 2\% } \\ \text { ethanol with patented additive, } \\ \text { reducing the amount of } \\ \text { harmful components in the } \\ \text { exhaust gases. }\end{array} \\ & 2 \% \mathrm{EKO}\end{aligned}$

Experiments were carried out after heating of engine and transmission oil by "run" on dynamometers drums with one person inside the car. For better accuracy every experiment was repeated for all planned meanings. With the purpose of reduction of the influence of ambient conditions on the experiment results, the experiments for every car were carried out on the same day. 


\section{Results}

After the measurement of the car power it was established, that the use of ethanol - based additives increased the VAZ - 21093 engine power (Fig 1), but the maximum power of VW Golf car engine was reached when petrol without additives (Fig 2) was used.

Changes of harmfulness of the engine exhaust gases at run speed $60 \mathrm{~km} / \mathrm{h}$ for different fuel blends and loadings are shown in Figs 3-6.

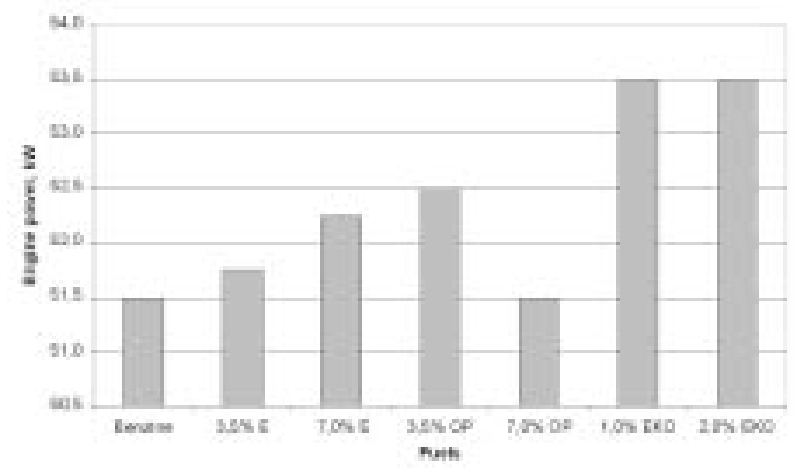

Fig 1. Dependence of VAZ - 21093 engine power on the sort of fuel

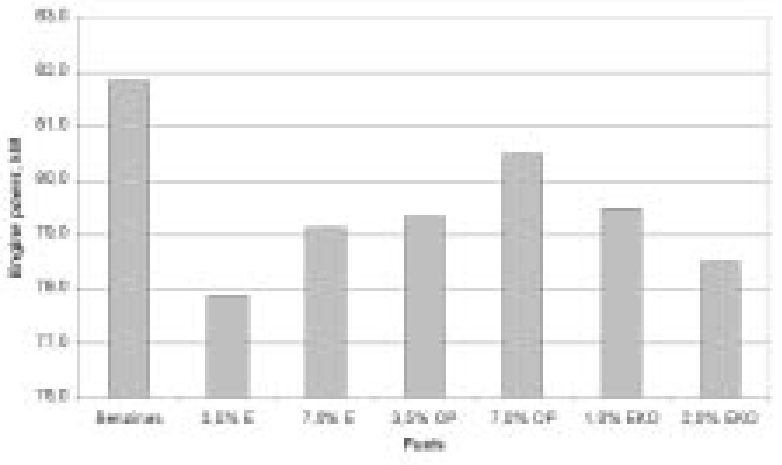

Fig 2. Dependence of VW Golf IV 1,6 1 16V engine power on the sort of fuel

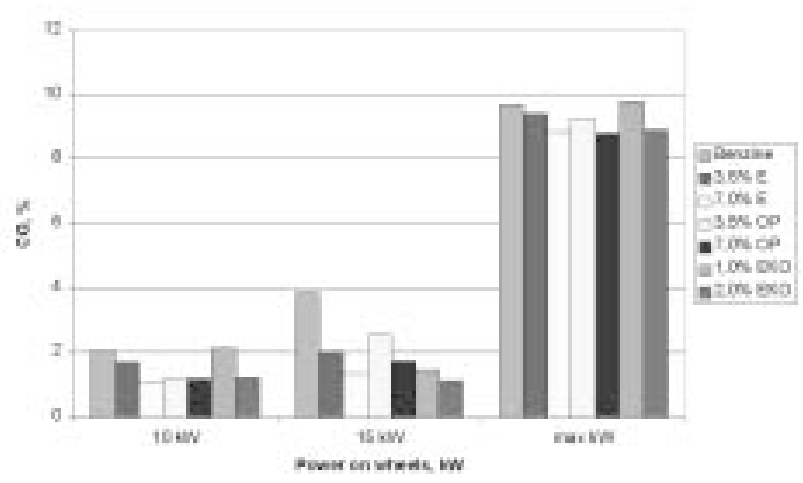

Fig 3. Dependence of CO emission on the sort of fuel at run speed $60 \mathrm{~km} / \mathrm{h}$ and different load for VAZ-21093 car
Fig 3 shows that almost in all cases $\mathrm{CO}$ emission is the highest when petrol without additives is used. It is so because of the use of the ethanol - based additives, having up to $36 \%$ of oxygen, which improves combustion.

Fig 4 shows that catalytic converter absolutely neutralizes the CO gases for VW Golf, when the car runs with the partially pressed accelerator, and only at full opening of the throttle the control unit enriches the intake mixture, and $\mathrm{CO}$ appears in the exhaust gases. The

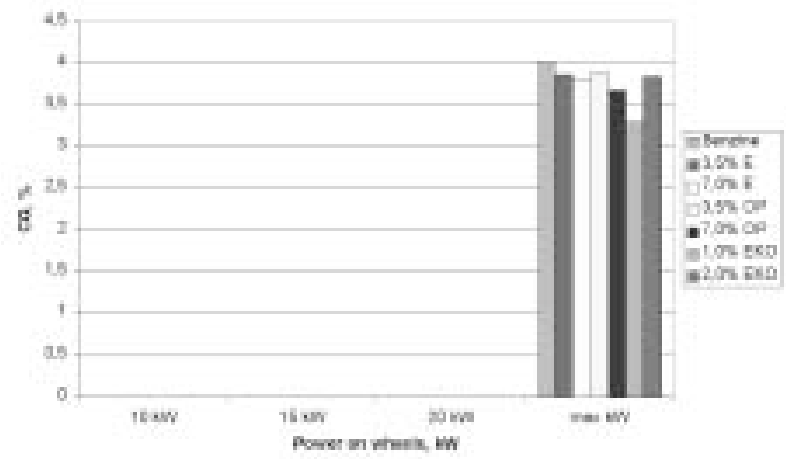

Fig 4. Dependence of CO emission on the sort of fuel at run speed $60 \mathrm{~km} / \mathrm{h}$ and different load for VW Golf IV 1,6116V car

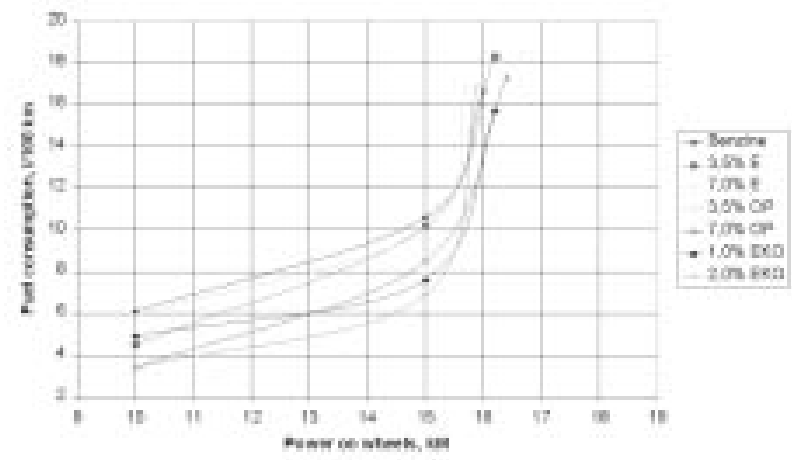

Fig 5. Dependence of fuel consumption on the sort of fuel at run speed $60 \mathrm{~km} / \mathrm{h}$ and different load for VAZ-21093 car

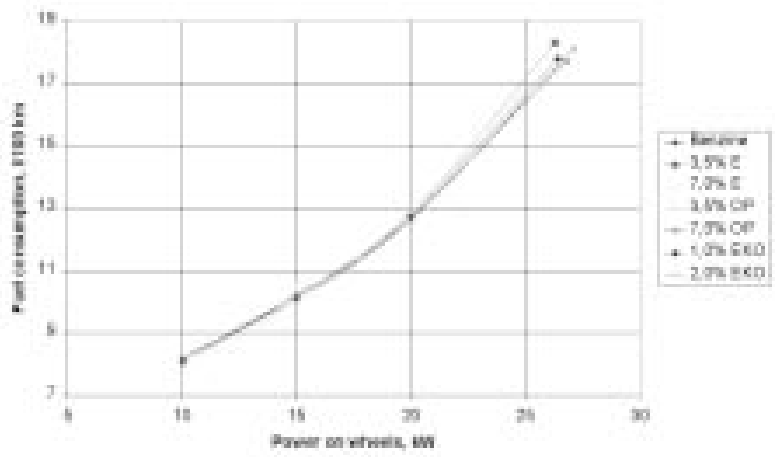

Fig 6. Dependence of fuel consumption on the sort of fuel at run speed $60 \mathrm{~km} / \mathrm{h}$ and different load for VW Golf IV 1,61 $16 \mathrm{~V}$ car 
experiments showed that the maximum amount of $\mathrm{CO}$ was when the engine is fed by petrol.

Figs 5 and 6 show changes in fuel consumption when different additives were used. Fig 5 shows fuel consumption of VAZ car. As the car prepares the combustion mixture in the carburetor, the steep ascend on the graph takes place at maximum loadings because of activation of the economizer. The graph shows that maximum fuel consumption corresponds to petrol without additives. Graph on Fig 6 shows (although insignificant, but difference can be seen), that maximum fuel consumption corresponds to $7 \%$ E blend. It can be understood, for the heating value of ethanol is more than two times less, if compared with petrol, therefore more fuel is necessary for the some power.

It can be seen that for power of 10,15 and $20 \mathrm{~kW}$ all additives had no significant influence on fuel consumption. For the maximum power (about $25 \mathrm{~kW}$ ) the use of the $7,0 \% \mathrm{E}$ blend reduced the engine power, but fuel consumption reached the maximum value. The average deviation of the specific fuel consumption for the maximum power for all blends did not exceed $\pm 0,18 \mathrm{l} /$ $100 \mathrm{~km}$. The largest difference of the consumptions was $18,3-17,2=1,11 / 100 \mathrm{~km}$.

\section{Conclusions}

1. The maximum power and the maximum torque were reached with the "EKO" additives for VAZ engine and petrol without additives - for VW Golf engine.

2. The maximum $\mathrm{CO}$ emission in the exhaust gases in almost all cases was with pure petrol (for the both cars).

3. The maximum fuel consumption was: for VAZ car working with pure petrol and for the VW Golf car with 7,0\% E blend.

4. It was observed that ethanol - based additives have different influence on power and ecological indications of cars with different feeding systems.

5 . The generalization of these research results does not allow to assert, that the "EKO" additive reduces the amount of harmful components in the exhaust gases. We suppose that ethanol, which was present in all the additives tested had some positive influence on the exhaust toxicity there.

\section{References}

1. The LAW on Biofuel of the Republic of Lithuania (Lietuvos Respublikos biokuro istatymas), 200007 18, No VIII-1875 Vilnius (in Lithuanian).

2. Methylated dehydrated ethyl alcohol. General requirements (Denatūruotas dehidratuotas etilo alkoholis. Bendrieji reikalavimai). LST 1706: 2000 (in Lithuanian).
3. Bureika, G. Research on the feasibility to use the ethanol as transport machine fuel: doctoral dissertation (Etanolio panaudojimo transporto mašinų variklių degalams galimybiu tyrimas: daktaro disertacija). Vilnius: VGTU, 1997. 177 p (in Lithuanian).

4. Gautam, M.; Martin, D. W.; Carder, D. Emissions characteristics of higher alcohol/gasoline blends. In: Proceedings of the Institution of Mechanical Engineers. Part A, Journal of Power \& Energy, 2000, Vol 214, No A2, p. 165-182. ISSN: 0957-6509.

5. Bureika, G.; Pukalskas, S. Research of noxiousness of the exhaust gases of petrol-ethanol blends. Transport engineering (Transportas), Vol XIII, No 2, Vilnius: Technika, 1998, p. 55-61 (in Lithuanian).

6. Deutsch, D. J. Fueling up ethanol. Chemical Engineering. 2000, Vol 107, No 11, p. 30-33. ISSN: 0009-2460.

7. Moreira, J. R.; Goidemberg, J. The alcohol program. Energy Policy, 1999 (27), p. 229-245.

8. Poulopoulos, S. G.; Samaras, D. P.; Philippopoulos, C. J. Regulated and unregulated emissions from an internal combustion engine operating on ethanol-containing fuels. Atmospheric Environment, 2001 (35), p. 4399-4406.

9. Furey, R. L.; Perry, K. L. Composition and reactivity of fuel vapor emissions from gasoline-oxygenate blends. In: SAE Paper 912429, 1991.

10. Gorse, Jr. R. A. The effects of methanol/gasoline blends on automobile emissions. In: SAE Paper 920327, 1992.

11. Salih, F. M.; Andrews, G. E. The influence of gasoline/ ethanol blends on emissions and fuel economy. In: SAE Paper 922378, SAE Fuel and Lubricants Meeting. 1992.

12. Palmer, F. H. Vehicle performance of gasoline containing oxygenates. International conference on petroleum based and automotive applications. Institution of Mechanical Engineers Conference Publications, MEP, London, UK, 1986, p. 33-46.

13. Abdel-Rahman, A. A.; Osman, M. M. Experimental investigation on varying the compression ratio of SI engine working under different ethanol-gasoline fuel blends. International Journal of Energy Research, 1997, No 21, p. 31-40.

14. Bata, R. M.; Elord, A. C.; Rice, R. W. Emissions from IC engines fueled with alcohol-gasoline blends: a literature review. Transactions of the ASME 111, 1989, p. 424-431.

15. Rice, R. W.; Sanyal, A. K.; Elrod, A. C.; Bata, R. M. Exhaust gas emissions of butanol, ethanol and methanol-gasoline blends. Journal of Engineering for Gas Turbine and Power, 1991, No 113, p. 337-381. 